\title{
Kuasa di balik harmoni: Etnografi kritis relasi etnis Tionghoa dan etnis Bali di desa Pupuan, Tabanan, Bali
}

\author{
I Gusti Made Aryana \\ Universitas Pendidikan Ganesha \\ Email: gustimadearyana@ymail.com
}

\begin{abstract}
Abstrak
Relasi antara etnis Tionghoa dengan masyarakat Desa Pupuan, Tabanan, Bali, berlangsung harmonis ditandai dengan perkawinan amalgamasi dan kesertaan mereka menjadi warga desa pakraman setempat. Artikel ini menganalisis relasi kuasa di balik hubungan harmonis tersebut. Ada tiga permasalahan dikaji: mengapa kedua etnis di Desa Pupuan hidup harmonis?; bagaimana dinamika kuasa di balik hubungan harmonis di desa Pupuan?; dan bagaimana model pendidikan dari perspektif etnopedagogik yang dilakukan oleh kedua etnis itu? Metode yang digunakan adalah deskriptif kualitatif berpendekatan etnografi kritis. Data dikumpulkan melalui wawancara mendalam, observasi, dan studi dokumentasi, serta dianalisis dengan model analisis interaktif dengan teori sosial kritis. Artikel ini menyimpulkan bahwa hubungan harmonis antaretnis terjadi karena ada kuasa dan modal yang dimainkan oleh kedua etnis. Dinamika kuasa di balik hubungan harmonis itu yang bersifat dinamis dan mencair, baik dalam aspek keagamaan, politik, sosial budaya, dan sosial ekonomi. Sementara itu, model pendidikan etnopedagogik yang ditumbuhkembangkan dengan menggunakan berbagai media, seperti organisasi sosial kemasyarakatan, aktivitas sosial dalam bentuk ngayah dan ngoupin, permainan tradisional, bercerita (mesatua), dan ritual budaya di ruang publik.
\end{abstract}

Kata Kunci: kuasa, harmoni, etnografi kritis, relasi etnis Tionghoa dan etnis Bali, etnopedagogik, desa Pupuan

\footnotetext{
Abstract

The relationship between Chinese and local society in Pupuan, Tabanan, Bali is realized through amalgamation marriage and participation as member of the local community organization of Desa Pakraman. This article analyzes the power
} 
relation behind the harmony. There are three problems to be discussed in this research i.e.: why the Chinese and Balinese ethnics at Pupuan Village live harmony?; how is the power dynamic behind the harmony relations in Pupuan Village?; and how is the model of education from etnopedagogic perspective which is conducted by two ethnics in Pupuan village? The research method applies qualitative descriptive method with critical ethnography approach. The data was gathered by deep interview, direct observation, and documents study and analyzed by interactive model with critis social theory.

The article concluded that the harmonius inter-ethnic relation is happened because power and capital which is played by two ethnics. The power dynamic behind harmonius relation is dynamic and dissolved, in term of religious, political, social cultural, and social economic aspect. In addition, etnophedagogic educational model developed by using variety of media such as media social organizations, social activities media through the model "ngayah" and "ngoupin", tradition game media, traditionmedia story telling (mesatua), and ritual culture media in public.

Keywords: power, harmony, critical ethnography, Chinese and Balinese ethnic, ethnopedagogic, Pupuan village

\section{Pendahuluan}

Desa Pupuan adalah salah satu desa tua di Kecamatan Pupuan, Tabanan, Bali. Secara demografi, desa ini berjumlah 3.265 jiwa $(851 \mathrm{KK})$ dan di dalamnya terdapat komunitas etnis Tionghoa sebanyak 113 (Monografi Desa Pupuan, 2015). Walaupun etnis Tionghoa ini sebagai kelompok minoritas, hubungan antarkeduanya berjalan harmonis. Etnis Tionghoa di desa itu melakukan perkawinan lintas etnis (amalgamasi), tidak lazim kebiasaan endogami atau seetnis yang berlaku pada etnis Tionghoa umumnya (Vasanty 1987:351-370). Di samping itu, juga melakukan ritual ala etnis Bali dan memiliki tempat pemujaan bernuansa Hindu, seperti sanggah kemulan, pelinggih Jro Gede, dan Taksu serta masuk menjadi anggota desa pakraman di Desa Pupuan.

Hubungan yang harmonis itu sangat paradoks dengan yang terjadi di luar Bali, seperti terlihat dalam beberapa kasus ketika etnis Tionghoa mendapat perlakuan diskriminatif dan berujung 
pada kekerasan fisik (Purdey, 2013:255-256). Fenomena sosial yang paradoks memberikan inspirasi untuk sebuah penelitian, terlebih penelitian tentang etnis Tionghoa di daerah pedalaman (perdesaan) masih langka (Habib, 2004:1-13). Kajian ini menjadi penting dan menarik dilakukan saat ini, karena ada gejala disintegrasi bangsa dan kerapuhan rasa persatuan bangsa, yang kini menjadi isu atau permasalahan nasional.

Kajian atas relasi harmonis antaretnik di Pupuan dilakukan dengan fokus mengapa etnis Tionghoa dan etnis Bali ini dapat hidup berdampingan secara harmonis? Bagaimana dinamika kuasa di balik hubungan harmonis tersebut? Bagaimana model pendidikan yang dilakukan oleh kedua etnis dalam menciptakan hubungan yang harmonis?

\section{Kajian pustaka}

Kajian tentang etnis Tionghoa dengan berbagai persoalan yang dihadapi sebagai etnis perantauan (diaspora) yang ada di berbagai kawasan pada umumnya dan di Indonesia pada khususnya banyak dikaji oleh para akademisi, terutama yang berada di pusat-pusat aktivitas perekonomiaan untuk melakukan aktivitas pada sektor pedagangan dan industri perkotaan (Habib, 2004:1-8). Sementara itu, kajian etnis Tionghoa yang ada di pedesaan masih langka.Di Bali, ada sejumlah penelitian tentang etnis Tionghoa di antaranya Geriya (2008), Sutjiati Beratha, dkk.(2010). Sementara itu, ada juga para sarjana yang mengkaji etnis Tionghoa di luar Bali seperti yang dilakukan oleh Charles A.Coppel (1994), Hari Poerwanto (2005), dan Jemma Purdey (2013).

Geriya (2008: 26-44) mendeskripsikan secara padat tentang kontribusi dan sinergi bermakna kedua etnis bagi dinamika kebudayaan dan peradaban lokal, nasional, dan universal. Metode yang digunakan adalah metode deskriptif kualitatif dan memakai analisis antropologis. Pendapat Griya secara substantif, hubungan antaretnis Tionghoa dan Bali di daerah Bali bersifat ekstensif dan intensif berbasis prinsip resiprositas, akulturatif, dan toleransi. Dijelaskan pula, karakteristik yang mengandung paralelisme dan persamaan telah mendorong terwujudnya integrasi kedua etnis dalam aspek budaya.

Sutjiati Beratha, dkk. (2010) lewat buku Dari Tatapan Mata ke Pelaminan Sampai di Desa Pakraman: Studi tentang Hubungan Orang 
Bali dengan Orang Cina di Bali mengkaji relasi harmonis etnis Cina di tiga lokasi, yaitu Desa Baturiti, Desa Carangsari, dan Desa Padangbai. Dilihat dari tujuan penelitian tersebut jelas berbeda dengan tujuan penelitian ini dan lokasi penelitiannya pun berbeda, walaupun sama-sama mengkaji keberadaan etnis Tionghoa.Di balik itu semua kajian tersebut memiliki relevansi dalam menganalisis hubungan dua etnis yang berbeda dan banyak memberikan wawasan bagi penulis untuk memahami lebih dalam kehidupan multikultural dan perkawinan lintas etnis serta implikasinya dalam berinteraksi di lapangan.

Karya Charles A.Coppel (1994) berjudul: Tionghoa Indonesia dalam Krisis, mengulas tentang latar belakang historis masalah etnis Tionghoa dan bagaimana terjadinya masalah tersebut serta bagaimana usaha masyarakat etnis Tionghoa di Indonesia untuk mengakomudasi diri dengan pasang surut politik nasional. Selain itu, disoroti juga olehnya tentang beberapa hal tentang etnis Tionghoa Indonesia yang merupakan tawanan dari situasi dan sejarah etnisnya sendiri. Menurutnya, sebagai etnis minoritas, tetapi relatif kaya dengan melakukan aktivitas perdagangan yang tidak seimbang, menimbulkan rasa antipati dari para pesaing usahawan Indonesia dan sangat berpengaruh di sektor ekonomi dan sering melakukan kesepakatan dengan pihak penguasa. Namun, jika terjadi prasangka anti Tionghoa dan terjadi pertentangan kepentingan terus berlanjut maka ada dilema yang terlalu erat dengan penguasa dapat menimbulkan malapetaka bagi mereka sendiri ketika pemerintah yang berkuasa dijatuhkan.

Karya Coppel yang komprehensif, tentang munculnya berbagai persoalan etnis Tionghoa (krisis etnis Tionghoa) di Indonesia. Demikian juga penelusurannya, menggunakan pendekatan temporal (historis), sejak kehadiran para imigran keturunan etnis Tionghoa melakukan persebaran (diaspora) ke Indonesia. Bagaimana perlakuan penguasa terhadap etnis Tionghoa dari zaman kolonial sampai pascakemerdekaan juga menjadi pembahasan Coppel. Uraian tersebut, sangat berbeda dengan kajian ini, hanya terbatas secara lokalitas dan substansial. Akan tetapi, karya Coppel itu sangat berguna bagi peneliti, dalam merunut dinamika kehidupan etnis Tionghoa di Desa Pupuan, yang juga tidak luput dari kebijakan yang dikenakan kepadanya sejak kedatangannya ke Desa Pupuan, baik era prakolonial (kerajaan), 
kolonial, maupun era pascakemerdekaan.

Hari Poerwanto (2005) dalam bukunya Orang Cina Khek dari Singkawang mengulas secara tentang usulan asimilasi untuk mengatasi masalah etnis Tionghoa di Indonesia, sejarah etnis Tionghoa di Indonesia, problematik etnis Tionghoa di Indonesia dalam hubungannya dengan asimilasi dan integrasi nasional, perantauan etnis Tionghoa di Kalimantan sejak zaman kolonial, dan asimilasi etnis Tionghoa di Singkawang. Menelisik karya Poerwanto tersebut sangat jelas fokus kajiannya di Kalimantan tentang kehidupan dan sejarah kehadiran etnis Tionghoa di Singkawang serta usulan yang diajukan untuk mengatasi persoalan etnis Tionghoa di Indonesia dengan asimilasi.

Berbeda dengan itu, kajian ini secara substantif dan terbatas pada aspek keruangan (lokalitas) yang hanya mengkaji sebuah desa yang ada di pegunungan (pedalaman), yaitu Desa Pupuan. Akan tetapi, karya Poerwanto amat membantu peneliti untuk dijadikan rujukan terutama sekali terkait penelusuran sejarah kehadiran etnis Tionghoa di Desa Pupuan secara khusus dan tentu saja tidak lepas dari kehadiran etnis Tionghoa di Indonesia pada umumnya.

Purdey (2013) dalam buku Kekerasan Anti Tionghoa di Indonesia 1996-1999, mengulas tentang: Indonesia-Tionghoa, minoritas di tengah-tengah, menyebarkan ketidakpuasan, meningkatnya sentimen anti-Tionghoa, klimaks, merepresentasikan dan mengingat, dan perubahan rezim dan transisi. Karya Purdey jelas berbeda dengan karya peneliti lakukan, sebab Purdey lebih banyak menyoroti tentang kekerasan yang menimpa etnis Tionghoa yang dilakukan oleh etnis non-Tionghoa, merupakan cerminan ketidakharmonisan yang terjadi. Sementara itu, kajian ini justru memaparkan keharmonisan yang terjadi antaretnis Tionghoa dengan etnis Bali di Desa Pupuan sampai saat penelitian ini dilakukan.

Selain karya-karya tersebut masih banyak karya-karya monumental dari para pakar (akademisi) yang membahas keberadaan etnis Tionghoa di dalam negeri maupun di luar negeri dengan segala persoalan yang dihadapi oleh etnis Tionghoa di perantauan, sepertiSuryadinata $(1986 ; 1988 ; 1999 ; 2002)$, Hadi (2009), Wirata (2000), dan Yuda (2014). Akan tetapi, hasil penelusuran pustaka membuktikan, belum ada yang membahas secara khusus dengan pendekatan etnografi kritis tentang relasi antardua etnis yang berbeda, tetapi tercipta sebuah harmoni. Walaupun ada yang 
bersinggungan dan mengambil lokasi penelitiannya sama, namun kajiannya sangat positivistis dan latar belakang ataupun rumusan problematiknya berbeda. Di samping itu, dari penelusuran pustaka, belum ada menunjukkan pembahasan yang lebih jauh mengenai terciptanya relasi yang harmonis antara dua etnis yang berbeda latar belakang budaya di Desa Pupuan, yang menggunakan pendekatan cultural studies dan pendekatan etnografi kritis.

\section{Metode penelitian}

Penelitian ini menggunakan metode deskriptif kualitatif dengan pendekatan etnografi kritis dalam perspektif kajian budaya (Spradley, 2006). Data dikumpulkan melalui wawancara mendalam dengan tokoh-tokoh masyarakat dari kedua etnis di Pupuan yang dianggap memahami persoalan yang diteliti, di antaranya Kepada Desa Pupuan, Bendesa Adat Pupuan, Ketua Organisasi Karang Semadhi dari etnis Tionghoa, Ketua Sekaa Truna-Truni, dan tokoh-tokoh masyarakat. Observasi langsung dilakukan terhadap lingkungan Desa Pupuan, tempat suci kedua etnis di Desa Pupuan, ritual, dan aktivitas sosial lainnya yang terjadi di lokasi penelitian. Sementara itu, studi dokumentasi dilakukan dengan mencari sumber berupa monografi dan profil Desa Pupuan, dan dokumen lainnya di berbagai tempat untuk memeperkuat temuan data yang dibutuhkan. Setelah data terkumpul maka dianalisis dengan model analisis interaktif (Milles dan Huberman, 1992) dengan bantuan teori sosial kritis sehingga menghasilkan sebuah etnografi kritis.

Beberapa teori yang digunakan adalah Teori Praktiknya Bourdieu (1984; 1986; 1990; 1991; 1992), yang pada prinsipnya mengatakan bahwa adanya permainan modal (ekonomi, sosial, budaya, dan simbolik) juga dapat menyebabkan terciptanya kehidupan harmonis. Oleh karena itu, teorinya Bourdieu berguna untuk menganalisis data yang berhubungan dengan alasan etnik Tionghoa dan masyarakat lokal Pupuan dapat hidup berdampingan secara harmonis. Sementara itu, teori Diskursus Kekuasaan/Pengetahuan Foucault (1980; 1997), pada intinya menyoroti bahwa kekuasaan itu ada di mana-mana dan siapa yang memiliki pengetahuan maka berarti pula memiliki kekuasaan. Atas dasar itu, dalam relasi etnis di Desa Pupuan ada permainan kuasa, menyebabkan terjadi dinamika dalam interaksi kedua 
etnis tersebut. Oleh karena itu, teori dari Foucault berguna juga untuk menganalisis data tentang terjadinya dinamika dalam relasi kedua etnis di Pupuan. Sementara itu, teori pendidikan Habermas (1971; Mukhlison, 2014), yang menekankan pentingnya sebuah komunikasi untuk menyelesaikan berbagai persoalan dengan melakukan negosiasi dan dialog yang dilakukan para agen/aktor di antara pihak yang berkepentingan untuk menemukan konsensus (kesepakatan). Teori itu juga berguna untuk membedah data yang terkait dengan model pendidikan etnopedagogik. Di samping teori utama itu digunakan pula teori lainnya, seperti teori Hegemoni Gramsci (1968), yang juga relevan dan digunakan secara eklektik. Selanjutnya hasil analisis data disajikan dalam bentuk deskriptif kualitatif dengan model induktif sebagaimana ciri khas dari studi kajian budaya dan dilengkapi pula dengan daya penjelas atau argumentatif secara kritis dengan bantuan teori sosial kritis.

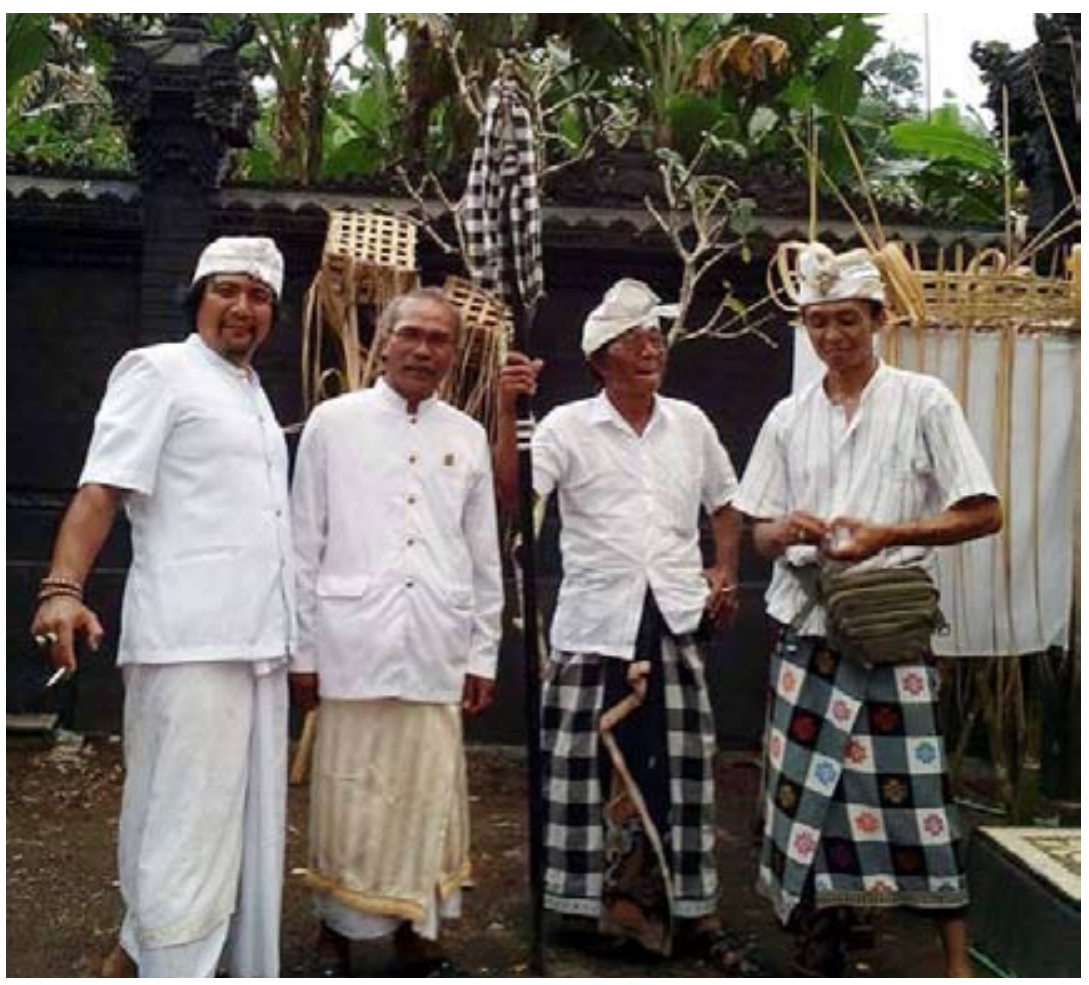

Foto 1: Keharmonisan antaretnis di Desa Pupuan, tampak pada saat ada ritual semuanya berpakaian adat Bali baik etnis Tionghoa maupun etnis Bali. Ketut Antawijaya alias Chan Kok An (paling kri) adalah peranakan etnis Tionghoa. 


\section{Relasi etnis Tionghoa dan etnis Bali di desa Pupuan}

Hasil penelitian menunjukkan bahwa berbagai alasan yang menyebabkan etnis Tionghoa dan etnis Bali di Desa Pupuan dapat hidup berdampingan secara harmonis, karena adanya permainan kuasa dan modal yang dimainkan oleh etnis Bali dan etnis Tionghoa sehingga kedua belah pihak menaati atau mengindahkan aturan yang dituangkan dalam Tri Hita Karana (THK) dan dijadikan pedoman dalam bertingkah laku oleh seluruh anggota (krama) desa setempat sehingga warga merasa terayomi, menuju kehidupan yang harmonis. Demikian juga kedua etnis di Desa Pupuan memainkan modal sosial dengan cara menumbuhkembangkan dan memelihara nilai-nilai kearifan lokal tentang persaudaraan (penyamabrayaan), yang dijadikan pilar terwujudnya rasa saling memiliki, menghormati, toleransi yang mengarah ke terciptanya hubungan yang harmonis.

Permainan modal sosial dan simbolik di antara mereka menyebabkan hubungan persaudaraan semakin tumbuh dan terpeliharadenganbaik, melaluiperkawinanlintasetnis(amalgamasi) di Desa Pupuan sehingga terciptanya ikatan kekerabatan yang semakin erat (in group) dan hubungan penyamabrayaan pun semakin intensif. Dengan demikian, masing-masing pihak berusaha mencegah munculnya keretakan (konflik) yang mungkin dapat terjadi sehingga hubungan harmonis tetap terpelihara dengan baik. Dengan adanya permainan modal yang dilakukan oleh kedua etnis untuk memenangkan kontestasi dalam upaya mempertahankan posisi masing-masing menyebabkan ada upaya untuk mengimbangi satu sama lain sehingga kondisi menjadi berimbang (balance) dan hal itu menjadi pemicu terwujudnya kehidupan yang harmonis.

Pernyataan di atas sejalan dengan pendapat dari Bapak Made Sukarya (65 tahun) yang kebetulan istrinya dari keturunan etnis Tionghoa, yang mengatakan bahwa:

“Sejak memperistri Cik Etjap (Alm.) hubungan kekeluargaan dengan keluarga istrinya berjalan cukup baik. Demikian pula, setiap ada pekerjaan atau acara yang bersifat suka dan duka selalu hadir di tengahtengah keluarga yang sedang melaksanakan hajatan atau acara dan juga sebaliknya dari keluarga istri".

Petikan wawancara tersebut mengindikasikan adanya permainan modal sosial dan simbolik di antara keluarga dari etnis 
Bali maupun dari keluarga etnis Tionghoa untuk tetap menjaga hubungan yang harmonis dengan jalan saling berkunjung dan membantu jika ada sebuah berhelatan, baik sifatnya suka maupun duka untuk mempererat hubungan persaudaraan (penyamabrayaan) di antara mereka. Dengan demikian di antara mereka berusaha untuk menghindari terjadinya kesalahpahaman yang dapat menyebabkan terjadinya keretakan hubungan. Oleh karena itu, semua pihak berusaha mengendalikan diri untuk tetap menjaga hubungan yang baik demi terwujudnya kehidupan yang harmonis walaupun berbeda etnis.

Tumbuhnya rasa senasib, seperjuangan, dan sepenanggungan akibat pengalaman sejarah yang dialami oleh kedua etnis etnis di Desa Pupuan mendorong pula adanya kesepakatan untuk hidup berdampingan secara damai (harmonis) dan berkomitmen untuk membangun desa bersama-sama, sebab Desa Pupuan dianggap olehnya sebagai tanah kelahiran dan miliknya. Demikian juga peran pihak eksternal, baik pemerintah pusat (negara) maupun pemerintah daerah (lokal) tidak dapat diabaikan, sebab mereka memiliki kepentingan untuk terciptanya kedamaian (harmoni) pada masyarakat sehingga dikeluarkan berbagai regulasi dan diatur melalui produk berupa aturan/perundang-undangan, seperti Perda No.3/2001 tentang Desa Pakraman (Surpha, 2012) dengan harapan tercipta tertib sosial (harmoni) dalam masyarakat.

Permainan modal yang dilakukan oleh kedua etnis dan ikut sertanya pihak eksternal memainkan modal kuasa maupun modal-modal lainnya menyebabkan terjadinya dinamika di balik hubungan harmonis antaretnis di Desa Pupuan. Dinamika tersebut bersifat dinamis atau mencair dan tidak dapat dilepaskan dari adanya dinamika sosial, ekonomi, budaya, dan politik (kekuasaan) yang terjadi di tingkat lokal ataupun nasional. Dinamika yang terjadi di tempat penelitian terjadi akibat dari adanya permainan kuasa dan pengetahuan (modal simbolik) seperti dalam teori kuasa/ pengetahuan Foucault dan teori praktik Bourdieu sehingga dapat dilihat dalam berbagai aspek, yaitu aspek agama dan keyakinan, yaitu terjadi sebagai akibat dari permainan modal kuasa (spiritual) oleh etnis Bali dan etnis Tionghoa dengan modal ekonomi dan sosialnya. Permainan modal tersebutoleh kedua etnis menyebabkan adanya dinamika kuasa di antaranya pada aspek itu untuk dapat saling menghegemoni, dalam arti kedua etnis itu dapat saling 
mengimbanginya, yaitu etnis Tionghoa dengan modal ekonomi dan sosialnya yang lebih unggul dapat mengimbangi dominasi etnis Bali yang memiliki modal kuasa spiritual dan simbolik juga dapat mengimbangi etnis Tionghoa yang unggul di bidang ekonomi.

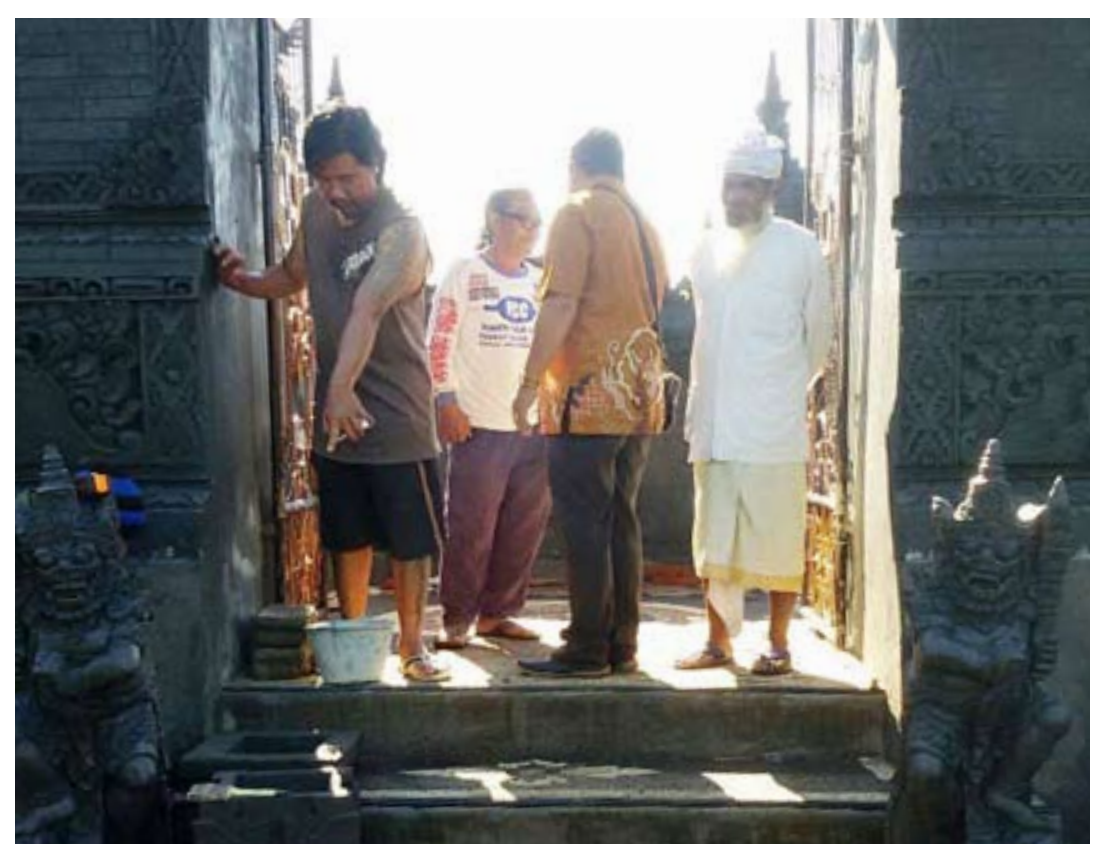

Foto 2. Pemangku Pura Griya Sari Ampel Gading sedang bergotong royong dengan warga dari etnis Bali dan etnis Tionghoa. Ketut Anta Wijaya selaku pimpinan proyek juga ikut mengawasi pekerjaan tersebut.

Sebagai bukti adanya saling menghegemoni di antara dua etnis itu, seperti hasil wawancara dengan sejumlah tokoh masyarakat termasuk Bendesa Adat Pupuan, I Wayan Meling (65 tahun) dan Ketut Anta Wijaya (46 tahun), ketua organisasi Karang Semadhi etnis Tionghoa, berikut. Bendesa Adat Pupuan I Wayan Meling mengatakan:

"Ketika etnis Tionghoa yang disebut nyama madelodan oleh etnis Bali membuat upakara ritual (ngodalin) di sanggah miliknya dibuatkan oleh tukang banten (serati) dari etnis Bali dengan membelinya sesuai dengan besar kecilnya ritual dan menyuruh Pemangku dari etnis Bali menghaturkan upakara ritual itu dengan memberikan semacam "sesari" sebagai ucapan terima kasih". 
Berdasarkan petikan dari wawancara itu, dapat dimaknai bahwa ada permainan modal antaretnis di Desa Pupuan untuk dapat memenangkan kontestasi di antara mereka, yaitu etnis Bali yang memiliki modal kuasa (spiritual) dan simbolik dapat menghegemoni etnis Tionghoa dengan menjual banten kepada etnis Tionghoa, di sini terjadi pertukaran nilai, tukang banten dapat imbalan berupa uang dari jasa pembuatan sarana upacara. Demikian juga rohaniawan (pemangku) yang menghaturkan ritual itu mendapat imbalan berupa "sesari" yang jauh lebih besar jika "sesari" yang diterima dari etnis Bali yang melakukan ritual yang sama atau sejenis. Oleh karena itu, dapat dikatakan bahwa etnis Tionghoa dengan modal ekonomi dan sosialnya dapat juga menghegemoni etnis Bali, sebab dengan mudah melakukan aktivitas ritualnya dengan menyerahkan sejumlah uang. Adanya kondisi saling menghegemoni itu menyebabkan terjadinya dinamika kuasa pada aspek keagamaan yang dapat membuat kondisi harmonis yang dinamis.

Pada aspek politik, cukup kentara adanya permainan kuasa dari pemerintah yang tercermin dari berbagai regulasi/kebijakan yang diambil dan ditetapkan oleh pemerintah (penguasa), baik oleh pemerintah pusat (negara) maupun pemerintah daerah (lokal). Secara politik penguasa (pemerintah) dengan kewenangan yang dimilikinya dapat memainkan modal kuasanya, yang tercermin dari fakta-fakta historis berbagai kebijakan yang dikeluarkan berupa undang-undang yang sifatnya mengikat semua warga. Kebijakan yang ditetapkan itu senantiasa dapat menimbulkan dinamika dalam interaksi kehidupan antaretnis di Desa Pupuan. Pada aspek sosial budaya, khususnya dalam pemakaian bahasa lokal, bahasa Bali, juga terjadi hegemoni etnis Bali dengan modal simbolik (pengetahuan) yang dimilikinya terhadap etnis Tionghoa, sehingga etnis Tionghoa dalam interaksi sosial selalu menggunakan sor singgih basa dan menyebabkan etnis Tionghoa belajar bahasa Bali untuk dapat berinteraksi dengan lingkungan sosialnya.

Selain pemakaian bahasa Bali, dinamika interaksi etnis Tionghoa dengan masyarakat Bali tampak pada aspek sosial ekonomi, khususnya kontestasi dalam perebutan SDA dan SDM dengan menggunakan kekuatan (modal) yang dimiliki oleh masingmasing etnis di Desa Pupuan. Etnis Tionghoa yang memiliki modal ekonomi dan sosial yang lebih kuat maka dalam kontestasi itu 
dapat memenangkan pertarungan menghadapi etnis Bali sehingga secara ekonomis/sosial etnis Tionghoa sampai saat ini lebih kuat dibandingkan dengan etnis Bali. Walaupun demikian, etnis Tionghoa tetap tidak arogan tetapi selalu bekerjasama dengan etnis Bali dengan menyuruh etnis Bali mengerjakan tanah perkebunan miliknya dan mengajak etnis Bali sebagai pekerja di toko miliknya. Dengan demikian dinamika hubungan di antara kedua etnis di Desa Pupuan berjalan cukup dinamis.

Dalam upaya menciptakan dan memelihara hubungan yang harmonis diantara etnis yang ada di Desa Pupuan maka dari perspektif etnopedagogik, model pendidikan yang ditumbuhkembangkan dan dipraksiskan oleh kedua etnis, dengan melakukan komunikasi atau dialog dengan lingkungan sosialnya sebagaimana teori komunikasi dari Habermas yang setiap saat harus dibangun dalam mengatasi kebuntuan yang terjadi dalam relasi antaretnis di Desa Pupuan. Untuk itu maka di lapangan ditemukan berbagai media yang digunakan untuk menumbuhkembangkan nilai-nilai kearifan lokal itu, di antaranya dengan menggunakan media organisasi sosial kemasyarakatan, seperti perkumpulan (sekaa) Truna-Truni (STT) dan Karang Taruna. Di samping itu dapat pula digunakan melalui media aktivitas sosial kemasyarakatan melalui model ngayah (kerja voluntir) dan ngoupin (membantu), model permainan tradisional, media tradisi mesatua (bercerita), dan media ritual budaya di ruang publik.

Adapun contoh dari aktivitas sosial "ngoupin" dan "ngayah" seperti pendapat dari mantan bendesa adat Pupuan, Jro Raka (56 tahun) dan Ketut Anta Wijaya (46 tahun), peranakan etnis Tionghoa di bawah ini.

“...ketika ada acara duka dan atau bersifat suka, misalnya kematian dan pernikahan, kedua etnis datang melayat, menyiapkan acara penguburannya dan datang membantu membuat perlengkapan pernikahan tersebut. Sementara itu, saat ada "pujawali" kedua etnik datang "ngayah" ke pura membuat perlengkapan upakara pujawali."

Kutipan wawancara ini menunjukkan kedua etnis ini mengembangkan nilai kearifan lokal, seperti nilai kerja sama, saling membantu, gotong royong, merekatkan hubungan persaudaraan, toleransi, yang semuanya itu sejalan dengan hakikat manusia sebagai makhluk sosial (homo socialis) yang senantiasa tidak 
dapat hidup sendiri tanpa bantuan orang lain sehingga penting berinteraksi dengan orang lain. Hal itu juga sejalan dengan ajaran Tri Hita Karana maupun ajaran Budha yang pada intinya mengajarkan keharmonisan hidup manusia di masyarakat.

Semua media tersebut cukup efektif digunakan untuk menanamkan nilai-nilai kearifan lokal, seperti kebersamaan, gotong royong, dan persaudaraan. Dengan demikian media tersebut dipergunakan untuk mengedukasi dengan mentransformasikan nilai-nilai kearifan lokal itu agar dapat dipraksiskan dalam kehidupan sosial dalam upaya mewujudkan kehidupan yang harmonis di Desa Pupuan.

\section{Simpulan dan saran}

Berdasarkan kajian yang dilakukan ada beberapa simpulan dan temuan yang didapat, yaitu Pertama, terciptanya hubungan yang harmonis antaretnis Tionghoa dan etnis Bali di Desa Pupuan karena adanya kepentingan, permainan kuasa dan modal yang dilakukan oleh kedua belah pihak, dikedepankannya toleransi, saling menghormati dan kesetaraan (equal) dalam keberagaman. Dengan demikian masyarakat Desa Pupuan dapat mengaktualisasikan motto Bhinneka Tunggal Ika dan doktrin multikulturalisme dalam kehidupan sosialnya. Jadi, kehidupan harmonis di Desa Pupuan Tabanan, Bali antaretnis Tionghoa dan etnis Bali dapat diwujudkan karena adanya permainan kuasa yang bersifat positif atau produktif sebagaimana dalam teori diskurkus kekuasaan/pengetahuan dari Foucault.

Kedua, terjadinya dinamika yang sangat dinamis dan bersifat mencair pada relasi antaretnis di Desa Pupuan akibat ada permainan kuasa (kekuasaaan) dari pihak internal (lokal) maupun eksternal (nasional) untuk ikut menciptakan situasi dan kondisi yang diinginkan, yaitu terciptanya stabilitas kehidupan sosial menuju kehidupan yang harmonis dapat dipertahankan pada masyarakat pluralistik. Dalam mempertahankan eksistensinya masing-masing etnis di Desa Pupuan selalu ada kontestasi pada arena yang sama untuk memperebutkan sumber daya ataupun posisinya dengan memainkan modalnya, seperti diteorikan oleh Bourdieu untuk memenangkan kontestasi. Namun dengan kearifan lokal yang dimiliki oleh kedua etnis melalui agency-nya melakukan negosiasi dan berdialog (komunikasi dibangun), seperti teori Habermas 
menyebabkan kondisi pada masyarakat di Desa Pupuan tetap kondusif (harmonis). Dengan demikian dalam konteks dinamika kuasa dapat dikatakan bahwa hegemoni yang terjadi di antara etnis Bali dan Tionghoa bukan saja bersifat searah, seperti teori Hegemoni Gramsci, yaitu etnis mayoritas menghegemoni etnis minoritas. Namun temuan menunjukkan bahwa hegemoni itu bersifat dua arah, yaitu ada kalanya etnis Bali menghegemoni etnis Tionghoa pada aspek tertentu dan sebaliknya ada kalanya etnis Bali terhegemoni oleh etnis Tionghoa pada bidang ekonomi. Jadi, terdapat semacam keseimbangan (power of balance) di antara kedua etnis dalam mengelola eksistensinya masing-masing sehingga keadaan harmonis dapat diwujudkan.

Ketiga, model pendidikan etnopedagogik yang dipraksiskan dalam rangka memelihara kehidupan harmonis antaretnis di Desa Pupuan dipergunakan berbagai media yang dianggap masih efektif untuk menanamkan nilai-nilai kearifan lokal secara lokalitas. Adapun berbagai media yang ditemukan di lapangan di antaranya, yaitu media organisasi sosial kemasyarakatan seperti sekaa taruna teruni dan karang taruna; aktivitas sosial ngayah dan ngoupin; permainan tradisional; bercerita (mesatua), dan ritual budaya di ruang publik. Melalui media tersebut semua pihak dapat menumbuhkan kesadaran betapa indahnya hidup dengan kebersamaaan, menyama braya, penuh toleransi dan saling menghargai satu sama lainnya yang sejatinya menjadi kunci dari hidup harmonis dengan lingkungan sosial sekitarnya.

\section{Ucapan Terima kasih}

Puji syukur penulis panjatkan ke hadapan Ida Sang Hyang Widhi Wasa (Tuhan Yang Mahaesa), karena atas asung kertha wanugrahaNya (rakhmat-Nya) penulis dapat menyelesaikan artikel ini. Terima kasih pula kepada pengelola Jurnal Kajian Bali, yang terhormat Prof. Dr. Phil. I Ketut Ardhana,M.A. dan Prof. Dr. I Nyoman Darma Putra, M.Litt., yang memberikan kesempatan kepada penulis untuk memasukkan naskah penulis untuk dimuat pada jurnal ini. Terima kasih pula kepada reviewer yang sudah banyak mengoreksi dan memberikan masukan untuk kesempurnaan naskah ini. 


\section{Referensi}

Agger, Ben. 2013. Teori-TeoriSosial Kritis: Kritik, Penerapan dan Implikasinya (Nurhadi Pentj.). Yogyakarta: Kreasi Wacana

Ardika, I Wayan. 2008. "Multikultural: Kearifan Lokal dengan Warga Tionghoa di Bali" dalam Sulistyawati (ed.). Integrasi Budaya Tionghoa ke Dalam Budaya Bali. Denpasar: Universitas Udayana

Beratha, Ni Luh Sutjiati, Ardika dan Dhana. 2010. Dari Tatapan Mata ke Pelaminan sampai di Desa Pakraman: Studi tentang Hubungan Orang Bali dengan orang Cina di Bali. Denpasar: Udayana University Press.

Bourdieu, Pierre. 1984. Homo Academicus, Traslated by Peter Collier. California: Stanford Univ.

Bourdieu, Pierre.1986. The Forms of Capital, In: Richardson J.G.(ed.) Handbook of Theory and Research of the Sociology of Education, pp.241258. New York: Greenwood Press

Bourdieu, P. 1990. The Logic of Practice. Palo Alto. Stanford Univ. Press.

Bourdieu, Pierre.1991.Languageand Symbolic Power. (Gino Raymond, Penerj.) Cambridge: Polity Press.

Bourdieu, Pierre.1992. An Invitation to Reflexive Sociology. Chicago: The University of Chicago Press.

Coppel, Charles A. 1994. Tionghoa Indonesia Dalam Krisis.Jakarta: Pustaka Sinar Harapan.

Foucault, Michel. 1980. Power/Knowledge. New York: Pantheon.

Foucault, Michel. 1997. Disiplin Tubuh, Bengkel Individu Modern. Yogyakarta: LKiS.

Geriya, I Wayan. 2008. "Pola Hubungan Antaretnis Bali dan Tionghoa dalam Dinamika Kebudayaan dan Peradaban" dalam Integrasi Budaya Tionghoa ke Dalam Budaya Bali (Sebuah Bunga Rampai), Sulistyawati (ed.). Denpasar: Universitas Udayana Bali.

Gramsci, A. 1968. Prison Notebooks. London: Lawrence \& Wishart.

Habib, Achmad. 2004. Konflik Antaretnik di Pedesaan: Pasang Surut Hubungan Cina-Jawa. Yogyakarta: LKiS.

Habermas, Jurgen. 1971. Knowledge and Human Interest. Boston: Beacon.

Hadi, Syamsul. 2009. Hubungan Indonesia Cina di Era Pasca Orde Baru: Perspektif Indonesia dalam Merangkul Cina Hubungan Indonesia Cina Pasca Orde Baru. Jakarta: PT.Gramedia Pustaka Utama

Milles, Matthew B. and A. Michael Huberman. 1992. Analisis Data Kualitatif. (Tjetjep Rohendi Rohidi, penterj.). Jakarta: UI Press 
Moleong, Lexy J. 2010. Metodologi Penelitian Kualitatif. Bandung: PT. Remaja Rosdakarya

Mukhlison, Moch. 2014. "Teori Pendidikan Kritis Jurgen Habermas" dalam Pendidikan Postmodernisme: Telaah Kritis Pemikiran Tokoh Pendidikan. Yogyakarta: Ar-Ruzz Media

Patria, Nezar, et.al. 2009. Antonio Gramsci: Negara \& Hegemoni. Yogyakarta: Pustaka Pelajar

Poerwanto, Hari. 2005. Orang Cina Khek dari Singkawang. Depok: Komunitas Bambu

Purdey, Jemma. 2006. Kekerasan Anti-Tionghoa di Indonesia 1996-1999. Denpasar:Pustaka Larasan

Spradley, James P. 2006. Metode Etnografi. Yogyakarta: Tiara Wacana

Sugiyono,2005. Metode Penelitian Kuantitatif, Kualitatif, dan $R \mathcal{E} D$. Bandung: Alfabeta

Sulistyawati, Made. 2008. Integrasi Budaya Tionghoa ke dalam Budaya Bali. Denpasar: Universitas Udayana

Sulthon, Ahmad. 2014. "Refleksi Pemikiran Pendidikan Michel Foucault" dalam Pendidkan Modernisme: Telaah Kritis Pemikiran Tokoh Pendidikan. Yogyakarta: Ar-Ruzz Media

Surpha, I Wayan. 2012. Seputar Desa Pakaraman dan Adat Bali. Denpasar: Pustaka Bali Post

Suryadinata, Leo. 1986. Politik Tionghoa Peranakan di Jawa. Jakarta: Sinar Harapan

Suryadinata, Leo.1988. Kebudayan Minoritas Tionghoa di Indonesia (Dede Oetomo, penterj.) Jakarta: PT. Gramedia

Suryadinata, Leo.1999. Etnis Tionghoa dan Pembangunan Bangsa. Jakarta: LP3ES.

Suryadinata, Leo.2002. Negara dan Etnis Tionghoa: Kasus Indonesia.Jakarta: LP3ES

Vasanty, Puspa. 1987. "Kebudayaan Orang Tionghoa Indonesia", dalam Koentjaraningrat, ed. Manusia dan Kebudayaan di Indonesia. Jakarta: Djambatan

Wirata, I Ketut. 2000. "Integrasi Etnis Tionghoa di Desa Adat Carangsari, Kecamatan Petang, Kabupaten Badung" Tesis S-2 Program Kajian Budaya Program Pascasarjana Universitas Udayana

Yudha, I Putu Putra Kusuma. 2014. “Perubahan Identitas Budaya Etnis Tionghoa di Desa Pupuan Kecamatan Pupuan Kabupaten Tabanan", Tesis S-2 Pascasarjana Program Studi Kajian Budaya Universitas Udayana 